\title{
PEMANFAATAN GEN 16S rRNA SEBAGAI PERANGKAT IDENTIFIKASI BAKTERI UNTUK PENELITIAN-PENELITIAN DI INDONESIA
}

\author{
Claudia Valleria Akihary ${ }^{1)}$, Beivy Jonathan Kolondam ${ }^{1)}$ \\ 1) Program Studi Biologi FMIPA UNSRAT Manado, 95115
}

\begin{abstract}
The 16S rRNA gene has hyper variable region and different for one bacterial species to another. The gene is being used as research tool to help for accurate identification of bacteria in many fields in Indonesia. As a useful tool, the 16S rRNA gene sequence is important as to explore the potencies of a bacterial species. Sequencing of this gene is very useful for research in clinical study, fisheries, marine science, agricultural science, and animal husbandry in Indonesia.
\end{abstract}

Keywords: $16 S$ rRNA gene, research tool, bacteria, Indonesia

\begin{abstract}
ABSTRAK
Gen 16S rRNA memiliki region yang sangat bervariasi dan berbeda setiap spesies bakteri. Penggunaannya sebagai perangkat penelitian, gen 16S rRNA telah banyak membantu dalam proses identifikasi berbagai jenis bakteri secara akurat untuk berbagai penelitian di Indonesia. Gen 16S rRNA tidak hanya dapat mengidentifikasi tetapi dapat dijadikan arahan dalam mengetahui potensi suatu bakteri. Sekuensing gen 16S rRNA telah digunakan secara luas untuk penelitian di bidang klinis, perikanan, kelautan, pertanian dan peternakan di Indonesia.
\end{abstract}

Kata Kunci: Gen 16S rRNA, perangkat penelitian, Bakteri, Indonesia. 


\section{PENDAHULUAN}

Gen 16S rRNA merupakan bagian dari prokariot yang memiliki bagian yang bersifat "terkonsevasi" (conserved). Selain gen ini, dikenal juga beberapa nukleotida lain yaitu gen $5 \mathrm{~S}$ rRNA dan gen $23 \mathrm{~S}$ rRNA yang juga digunakan dalam pengidentifikasian namun dinilai sulit dalam analisis. Gen 5S rRNA memiliki panjang 120 nt. Pada prokariotik, 5S rRNA mengikat pada protein ribosomal: L5, L18, L25. 5S rRNA jika dijadikan metode dalam mengidentifikasi dinilai sangat sulit. Hal ini dikarenakan terlalu kecil dan dalam beberapa kasus pada Archae dan Prokariot didapati 5S rRNA bermodifikasi sehingga tidak akurat jika dilakukan analisis filogenik. Gen 23S rRNA memiliki 2900 basa dan juga dinilai menyulitkan analisis statistika, karena memiliki struktur tersier dan sekunder yang cukup panjang (Jusuf, 2001).

Dalam pemanfataanya, gen $16 \mathrm{~S}$ rRNA banyak digunakan dalam berbagai bidang terkait dengan keuntungannya terutama dalam hal identifikasi. Gen ini memiliki banyak sekali manfaat sehingga dijadikan sebagai Gen Penanda. Gen 16S rRNA telah banyak digunakan di berbagai bidang penelitian maupun untuk tujuan praktis karena dinilai cepat dan praktis.

\section{KELEBIHAN DAN KEKURANGAN METODE IDENTIFIKASI MENGGUNAKAN GEN 16S rRNA}

Pemanfaatan gen 16S rRNA untuk metode deteksi molekuler dianggap memiliki tingkat diskriminasi yang rendah karena sebagian besar hasil runutan DNA 16S rRNA menunjukkan adanya kesamaan yang tinggi di dalam satu spesies. Apabila homolgi sekuen 16S rRNA menunjukkan $<97.5 \%$ dapat dikatakan sebagai spesies yang berbeda atau novel spesies (Stackbrant dan Gobel, 1994). Dengan metode gen 16S rRNA dapat digunakan untuk identifikasi jika didapati sulit untuk mengidentifikasi bakteri secara fisiologi. Selain identifikasi secara fisiologis, uji biokimia juga bila dirasa tidak dapat dikenali maka metode ini dapat dijadikan sebagai alternatif (Janda dan Abbott, 2007).
Menurut Pangastuti (2006), gen 16S rRNA memiliki berbagai keunggulan yaitu (1) Bersifat ubikuitas dengan fungsinya yang bersifat identik pada setiap organisme; (2) Gen 16S rRNA dapat berubah sesuai jarak evolusinya sehingga dapat digunakan sebagai kronometer evolusi; (3) Gen 16S rRNA memiliki bagian yang bersifat konservatif untuk mengontruksi pohon filogenetik universal; (4) Memiliki bagian hyper variable region yang memudahkan untuk mengidentifikasi jenis bakteri. Keuntungan dari Gen 16S rRNA, berdasarkan penelitian Dewa et al. (2015), yaitu dapat melihat kemiripan antar spesies bakteri. Kemiripan yang didapati antar spesies dengan metode ini yaitu $99 \%$. Kemiripan yang didapat juga dapat di kelompokkan dalam dua kelompok yaitu kemiripan yang cukup tinggi dan kemiripan yang cukup jauh (rendah). Dengan metode Gen 16S rRNA, suatu genus dikatakan mirip apabila memiliki kemiripan $97 \%$ dan dikatakan satu spesies apabila kemiripan yang diperoleh 99\% (Petti, 2007).

Dilihat dari keuntungannya, gen $16 \mathrm{~S}$ rRNA nyatanya sangat efektif digunakan karena memiliki keakuratan yang tinggi dan juga tidak memakan waktu dalam pengidentifikasiannya. Sama halnya dengan metode-metode lainnya, metode ini memiliki kekurangan dalam beberapa hal. Kekurangannya ini didapati melalui beberapa penelitian yang menggunakan penelitian dan mendapati kendala.

Kekurangan pertama, gen 16S rRNA memiliki morfologi yang sama walaupun spesies berbeda. Walaupun telah diidentifikasi secara molekuler, belum dapat menjamin morfologi atau fenotip yang diamati akan sama. Melalui penelitian Napitupulu et al. (2019), yang berbeda dalam hal ciri-ciri (ukuran, warna, elevation, dan bentuk koloninya) akan tetapi diidentifikasi tergolong dalam genus bakteri yang sama yaitu Basillus sp. Ketidaksama fenotip juga dapat disebabkan karena penggunaan metode. Metode fenotip apabila dilakukan berulang-ulang akan memberikan hasil yang berbeda pula. Berdasarkan penelitian Nurkanto dan Agusta (2015), spesies yang didapatinya memiliki 
perbedaan berdasarkan warna koloni, kemampuan asimilasi gula, toleransi salinitas dan $\mathrm{pH}$ juga resisten beberapa antibiotic. Walaupun secara molekuler menggunakan metode 16S rRNA, sekuen gen dari kedua bakteri tersebut identik.

Kekurangan kedua, diperlukan beberapa langkah untuk menggabungkan identifikasi secara fenotip, genotip dan informasi filogenik. Melalui penelitian yang dilakukan oleh Suryadi et al. (2013), diperoleh tujuh isolat yang enam diantaranya diprediksi berpeluang sebagai novel spesies. Keenam isolat tersebut memiliki kemiripan morfologi dan sekuen, sehingga perlu ditambahkan langkah selanjutnya yaitu metode polifasik. Metode polifasik ini dianggap lebih akurat dan terpercaya karena prinsip dari metode ini adalah menggabungkan semua informasi fenotip, genotip dan informasi filogenik yang diperoleh.

Polifasik merupakan pendekatan sistematik mikroba seperti bakteri baiknya menggunakan metode ini (Idramsa, 2013). Polifasik ini menggunakan atau berdasarkan informasi sekuen gen 16S rRNA yang dijadikan dasar dalam pengidentifikasian dan validasi dengan mengamati banyak karakter fenotik, genotik $(G+C$ content, DNA-DNA similarity dan DNA-rRNA similiarity) dan kemotaksonomi (Idramsa, 2013).

\section{PEMANFAATAN SEKUENSING 16S IRNA UNTUKPENELITIAN DI INDONESIA}

\section{Bidang Klinis}

Di bidang klinis, metode 16S rRNA termasuk sebagai prosedur dalam diagnosis suatu penyakit. Metode 16S rRNA sebagai diagnosis suatu penyakit memang belum banyak digunakan terkait dengan biaya pemeriksaan yang mahal. Jika dilihat dari spesifitas dan sensitivitasnya yang tinggi, metode ini dinilai sangat akurat dan cepat dalam hal mengidentifikasi berbagai sampel klinis (Rinanda, 2011).

Menurut Nolte (2008), mengidentifikasi bakteri dari saluran pernapasan tidak akurat jika menggunakan metode mikrobiologi konvensional. Menurut Rinanda (2011), pendekatan molekuler dinilai tepat dan akurat dibandingkan metode mikrobiologi konvesional. Sehingga mikrobiologi konvesional tidak lagi dimasukkan dalam pedoman penatalaksanaan.

Berdasarkan penelitian Radji et al. (2010), identifikasi bakteri E. coli secara konvesional melalui uji biokimia memakan waktu yang lama dan cenderung sulit dilakukan. Penelitian Sikome et al. (2018), mendapati jenis bakteri pada penderita ISK (Infeksi Saluran Kencing) yaitu Klebsiella pneumonia. Bakteri ini didapat dengan mengamplifikasi gen $16 \mathrm{~S}$ rRNA dengan tingkat kemiripan 99\%.

Bakteri dapat ditemukan di mana saja misalnya di tanah, udara, air bahkan di dalam tubuh organisme. Bahkan di tempat yang tidak diduga seperti pada spons untuk mencuci piring. Spons yang sering digunakan mempunyai kemungkinan terdapat bakteribakteri penyebab penyakit yang berbahaya bagi manusia. Penelitian Gaffar et al. (2014) mendapati bakteri E. coli sebagai bakteri pathogen penyebab penyakit pada spons cuci piring. Gen bakteri ini berhasil diamplifikasi pada panjang fragmen gen $16 \mathrm{~S}$ rRNA mendekati $1400 \mathrm{bp}$.

\section{Bidang Perikanan dan Kelautan}

Di bidang kelautan dan perikanan, beberapa penelitian menggunakan Gen 16S rRNA telah banyak dilakukan. Umumnya penelitian di bidang ini bertujuan untuk mengidentifikasi beberapa bakteri yang bukan hanya dapat menyebabkan penyakit tetapi dapat menghasilkan metabolit yang dapat dimanfaatkan kembali di berbagai bidang.

Dari penelitian Ramadhan et al. (2016), dijelaskan bahwa bakteri yang diidentifikasi merupakan bakteri yang bersimbiosis dengan beberapa makroalga dan dapat menghasilkan enzim selulase. Enzim ini umumnya dapat ditemui di alam dan dapat digunakan seperti untuk produksi bioethanol. Dengan ditemui bakteri yang dapat mengsekresikan enzim selulase ini pada substratnya diharapkan produksi enzim tersebut lebih optimal. Untuk mengidentifikasi bakteri tersebut digunakan Gen 16S rRNA. Dari penelitian ini didapati dua jenis bakteri 
yang memiliki kesamaan nukleotida diatas $80 \%$.

Beberapa penelitian identifikasi untuk mikroorganisme laut melalui skala DNA dan molekuler khususnya di Sulawesi Utara masih minim. Beberapa penelitian dilakukan dengan gen penyandi yaitu Gen $16 \mathrm{~S}$ rRNA untuk meneliti bakteri yang hidup di perairan malalayang, Sulawesi Utara. Salah satu contohnya penelitian yang dilakukan Untu et al. (2015) untuk mendapakan salah satu bakteri pada tubuh organisme invertebrate laut. Hasil penelitian tersebut mendapati kemiripan mikroba 99\%. Untuk kemiripannya sendiri diperoleh dari nilai total dari jumlah basa mikroba pada GenBank dibagi dengan total jumlah basa yang sama dengan sampel mikroba (Untu et al., 2015).

Penelitian Napitupulu et al. (2019) mendapati dua jenis bakteri yang masuk dalam genus yang sama yaitu Bacillus sp. yang merupakan bakteri pengurai pada rotifer. Rotifer merupakan salah satu organisme yang mampu hidup di perairan yang kotor. Bahkan perairan yang mengandung banyak detritus dan nanoplankton dapat menambah banyak jumlah rotifer. Setelah dilakukan identifikasi secara molekuler didapati bakteri yang berfungsi sebagai pengurai. Dengan gen $16 \mathrm{~S}$ rRNA didapati bakteri Basillus sp. dengan Expect value 0. Expect value menunjukkan nilai dugaan dan jika menunjukkan nilai dugaan 0 maka menandakan bahwa hasil sekuens kedua jenis bakteri tersebut identik.

Selain dapat mengindentifikasi jenis bakteri diperairan, Gen 16S Rrna terbukti dapat mengidentifkasi status taksonomi ikan. Melalui penelitian Nugroho dan Rahayu (2015), tentang Taksonomi ikan Nomei di Perairan Tarakan berdasarkan gen 16S rRNA, terindentifikasi ikan jenis Saurida undosquamis dengan tinggkat kecocokan 91\%. Selain dapat mengindentifikasi jenis ikan Nomei di perairan tersebut, dapat juga melihat topologi filogentik dan dengan adanya spesies outgrup dapat memperkuat status taksonomi dari ikan Nomei.

Berdasarkan penelitian Dewi et al. (2018) penggunaan gen 16S rRNA sebagai gen penyandi dapat bertujuan untuk mengetahui suber Bioluminesensi pada ikan lumek. Ikan lumek yang mati pada awalnya belum diketahui asal sumber cahaya yang dihasilkan. Melalui penelitian ini didapati cahaya yang dihasilkan berasal dari bakteri luminesen yang memungkinkan ikan dapat memancarkan cahaya pada permukaan kulitnya 8 sampai 9 jam setelah kematian. Bakteri ini diketahui merupakan bakteri gram negatif, bersifat motile dan dapat menfermentasikan glukosa.

\section{Bidang Pertanian}

Di bidang pertanian, gen $16 \mathrm{~S}$ rRNA ini juga memiliki manfaat yang hampir sama yaitu pengidentifikasi bakteri dengan manfaat untuk menemukan bakteri yang dapat menyebabkan penyakit pada tanaman dan dapat menyebabkan penurunan produksi pangan. Selain itu juga dapat diidentifikasi bakteri yang bersifat endofit sehingga dapat dimanfaatkan sebagai salah satu organisme penghasil metabolit sekunder yang bermanfaat.

Berdasarkan penelitian Sari (2014) melakukan identifikasi terhadap aktinomiset endofit asal tanaman padi berdasarkan analisis Gen 16S rRNA dan nifH. Penelitian ini memperoleh enam jenis bakteri yang berbeda dengan kesamaan morfologi koloni. Enam jenis bakteri ini memiliki identitas maksimum $<97 \%$ dengan E-value 0,0 dan keenamnya digolongkan ke dalam Streptomyces spp.

Pengidentifikasian dengan 16S rRNA pada penelitian Suryadi et al. (2013) memperoleh empat jenis bakteri yang teramplifikasi pada daerah sekitar $1.300 \mathrm{bp}$. Penelitian ini juga berhasil menemukan isolat bakteri yang memiliki kemiripan 99\% dengan bakteri Burkholderia sp. dengan panjang basa nukleotida 1.322 bp. Bakteri-bekteri ini di isolasi dari padi yang berasal dari 10 lokasi di daerah Sukabumi. Bakteri- bakteri ini merupakan bakteri endofitik yang berfungsi sebagai penghambat jamur patogen pada padi.

Pada umumnya metode ini dapat mengidentifikasi berbagai jenis bakteri dimanapun contohnya pada bakteri yang diisolasi dari oncom merah yang telah difermentasi 24 jam dengan tujuan mendapatkan bakteri yang dapat menghasilkan 
enzim protease. Melalui penelitian didapati bakteri Bacillus thungiensis yang juga positif dapat menghasil enzim protease yang baik. Bakteri yang telah diisolasi tadi memiliki kemiripan 98\% dengan fragmen gen $16 \mathrm{~S}$ rRNA pada Bacillus thungiensis (Safitri et al., 2018).

Berbeda dengan penelitian-penelitian di atas, penelitian Widaranti et al. (2016) mengidentifikasi bakteri yang bersimbiosis dengan akar tanaman teh. Melalui penelitian ini didapati tiga jenis bakteri yang masuk pada golongan rhizobacteria.

Penelitian Nisa (2018) menggambarkan tentang isolasi dan identifikasi bakteri pelarut dengan sekuen 16S rRNA asal tanah pertanian organik Desa Sumberejo batu. Penelitian ini memperoleh bakteri tanah yang memiliki kedudukan pada clade yang sama dengan bakteri Klebsiella pneumonia strain DSM 30104 dengan similaritas $98 \%$. Bakteri ini memiliki potensi untuk menghasilkan IAA yang merupakan asam yang dapat melarutkan fosfat.

\section{Bidang Peternakan}

Penggunaan Gen 16S rRNA sebagai tool dalam mengidentifikasi bakteri sangat luas dan dapat digunakan di bidang apa saja termasuk bidang peternakan. Pemanfaatan Gen 16S rRNA di bidang peternakan memainkan peran dalam pengidentifikasian bakteri yang menyebabkan penyakit pada hewan ternak dan juga bakteri yang bersifat menguntungkan.

Bakteri yang bersifat menguntungkan seperti BAL (Bakteri Asam Laktat). BAL yang ditemui pada usus sapi terbukti dapat menghambat pertumbuhan $S$. aureus sebesar $50,35 \% \quad(36,56-61,47 \%)$. BAL ini didentifikasi dari bakteri asam laktat isolate 9A berpotensi dengan menggunakan gen $16 \mathrm{~S}$ rRNA (Widyadnyana et al., 2015).

Pada penelitian Yurleni et al. (2014), salah satu cara meningkatkan produktivitas ternak dengan meningkatkan aktivitas dan populasi mikroba pada rumen ternak yaitu BAL. BAL yang diperoleh dapat berasal dari mana seperti berasal dari durian fermentasi asal jambi.
Beberapa penelitian yang menggunakan rumen sapi mendapati berbagai bakteri. Noor et al. (2014) mendapati jenis bakteri yang dapat menghasilkan gas metana yang nantinya dapat digunakan sebagai alternatif biogas. Gen bakteri target yang diperoleh memiliki panjang ukuran insert yaitu 800 bp dengan total klon 51.

\section{KESIMPULAN}

Berdasarkan penelitian-penelitian dari berbagai bidang yang telah dilakukandi Indonesia menggunakan gen $16 \mathrm{~S}$ rRNA, dapat dikatakan bahwa gen ini merupakan perangkat yang memiliki keakuratan yang tinggi dengan penggunaan yang luas. Gen $16 \mathrm{~S}$ rRNA tidak hanya dapat mengidentifikasi tetapi dapat dijadikan arahan dalam mengetahui potensi suatu bakteri.

\section{DAFTAR PUSTAKA}

Dewa Gede Agung Widyadnyana, I Dewa Made Sukrama, dan I Wayan Suardana. 2015. Identifikasi Bakteri Asam Laktat Isolat 9A dari Kolon Sapi Bali sebagai Probiotik melalui Analisis Gen 16S rRNA. JS. 33 (2): 228-233.

Dewi, Kartika, D. Pringgenies., Haeruddin dan S. Muchlissin. 2018. Fenomena Bioluminesensi Ikan Lomek (Harpadon nehereus) Berasal dari Bakteri luminesen. JPHPI 21(3): 451459.

Gaffar, Shabarni., I. Maksum dan E. Juleha. 2014. Identifikasi Populasi Bakteri dalam Spons Pencuci Piring dengan Metode PCR-RFLP. Chimica et Natura Acta 2(2):120-125.

Idramsa. 2013. Peran Sistematik Mikrobia dalam Mengungkap Keanekaragaman Mikroorganisme. Jurnal Keluarga Sehat Sejahtera 11(2): 58-63.

Janda, M dan Abbott, S. 2007. 16S rRNA Gene Sequencing for Bacterial Identification in the Diagnostic Laboratory: Pluses, Perils and Pitfalls. Journal of Clinical Microbiology 45: 2761-2764

Jusuf, M. 2001. Genetika 1: Struktur dan Ekspresi gen. IPB. Bogor 
Napitupulu, H., I. Rumengan., S.Wulur., E.Ginting., J. Rimper., dan Toloh, B. 2019. Bacillus sp. sebagai Agensia Pengurai dalam Pemeliharaan Brachionus rotundiformis yang menggunakan Ikan Mentah sebagai Sumber Nutrisi. Jurnal Ilmiah Platax 7(1): 158-169.

Nisa, Nurullah. 2018. Isolasi dan Identifikasi Bakteri pelarut dengan Sekuen 16S rRNA Asal Tanah Pertanian Organik Desa Sumberejo Batu. Skripsi. UIN Malang.

Nolte, F.S. 2008. Molecular Diagnostics for Detection of Bacterial and Viral Pathogens in Community-Acquired Pneumonia. CID 47:123-6.

Noor, S., H. Pramono dan S. Aziz. 2014. Deteksi Keanekaragaman Spesies Bakteri Metanogen Rumen Sapi Menggunakan Kloning Gen 16S rRNA dan Sekuensing. Scripta Biologica 1(4): 1-8.

Nurkanto, A dan A. Agusta. 2015. Identifikasi Molekular dan Karakterisasi MorfoFisiologi Actiomycetes Penghasil Senyawa Antimikroba. Jurnal Biologi Indonesia 11(2): 195-203.

Nugroho, D. dan Rahayu D. 2015. Status Taksonomi Ikan Nomei Dari Perairan Tarakan, Kalimantan Utara Berdasarkan Gen 16S rRNA Sebagai Upaya Konservasi Ikan Laut Lokal Indonesia. Jurnal Harpodon Borneo 8(2): 132-141.

Pangastuti, A. 2006. Definisi Spesies Prokaryota Berdasarkan Urutan Basa Gen Penyandi 16S rRNA dan Gen Penyandi Protein. Biodiversitas 7(3): 292-296.

Petti, P. A. 2007. Detection and identification of microorganisms by gene Amplification and Sequencing. Clin. Infect Disc. 44(8):1108-1114.

Radji, M., Puspaningrum, A dan Sumiati, A. 2010. Deteksi Cepat Bakteri Escherichia coli dalam Sampel Air dengan Metode Polymerase Chain Reaction Menggunakan Primer 16E1 dan 16E2. J. Makara Sains 14(1): 3943.

Ramadhan, Muhammad L., I. Buwono., dan Y. Mulyani. 2012. Analisis Potensi dan Karakterisasi Molekuler Gen 16S rRNA Bakteri Selulotik yang di Isolasi dari Makroalga Euchema sp. dan Sargassum sp. Sebagai Penghasil Enzim Selulase. Jurnal Perikanan dan Kelautan 3(3): 61-67.

Rinanda, T. 2011. Analisis Sekuensing 16S rRNA Di Bidang Mikrobiologi. $J$. Kedokteran Syiah Kuala 11(4): 172177

Sari, Wahyu Eka. 2014. Identifikasi Aktonomiset Endofit Asal Tanaman Padi Berdasarkan Analisis Gen 16S rRNA dan nifH. Tesis. Bogor: IPB. 71 hal

Safitri, R., S. Muchlissin., A, Mukaromah., S. Darwati dan S. Ethica. 2018. Isolasi Bakteri Penghasil Enzim Protease Bacillus thungiensis irodi pada Oncom Merah Pasca Fermentasi 24 Jam. Seminar Nasional Edusaintek. Hal 6269.

Stackebrandt, E dan Gobel, B. 1994. A place for DNA-DNA reassociation and $16 \mathrm{~S}$ Ribosomal RNA Sequence Analysis in The Present Species Definition in Bacteriology. Int. J. Syst. Bacteriol. 44: 846-849.

Sikome, C., Fatmawati dan T. Tallei. 2018. Isolasi dan Identifikasi Secara Biomolekuler Bakteri Penyebab Penyakit Infeksi Saluran Kemih Yang Resisten Terhadap Antibiotik Ciprofloxacin di RSUP Prof. Dr. R. D. Kandau Manado. Pharmacon 7(2): $62-$ 70.

Suryadi, Y., T, Priyatno., I.M. Samudra., D. Susilowati., Patricia dan Irawati, W. 2013. Karakterisasi dan Identifikasi Isolat Bakteri Endofitik Penghambat Jamur Patogen Padi. Buletin Plasma Nutfah 19(1): 25-32

Untu, P., I, Rumengan dan E, Ginting. 2015. Identifikasi Mikroba yang Koeksis dengan Ascidia Lissoclinum patella Menggunakan Sekuens Gen 16S 
rRNA. Jurnal Pesisir dan Laut Tropis. 2(1): 23-33.

Widyadnyana,D ., I, Sukrama dan Sudarna, I. 2015. Identifikasi Bakteri Asam Laktat Isolat 9A dari Kolon Sapi Bali sebagai Probiotik melalui Analisis Gen 16S rRNA. Jurnal Sain Veteriner 33(2): 228-233.

Widaranti, A., S, Jannah., H, Pancasakti K., dan D. Susilowati. 2016. Komunitas Rhizobakteria Tanaman Teh dengan Aplikasi Formula Bioimunizer (Chryseobacterium sp. dan Bacillus sp.) berdasarkan Gen 16S rRNA. Jurnal Biologi 5(4): 40-50.

Yurleni. 2013. Produktivitas dan Karakteristik Daging Kerbau dengan Pemberian Pakan yang Mengandung Asam Lemak Terproteksi. Tesis. Bogor: IPB. 